\title{
A FAIR PLAY ACCOUNT OF LEGITIMATE POLITICAL AUTHORITY*
}

\author{
Justin Tosi \\ University of Michigan
}

\begin{abstract}
There is an emerging consensus among political philosophers that state legitimacy involves something more than-or perhaps other than-political obligation. Yet the principle of fair play, which many take to be a promising basis for political obligation, has been largely absent from discussions of the revised conception of legitimacy. This paper shows how the principle of fair play can generate legitimate political authority by drawing on a neglected feature of the principle-its stipulation that members of a cooperative scheme must reciprocate specifically by submitting to the scheme's rules.
\end{abstract}

The modern debate about state legitimacy began with the publication of Robert Paul Wolff's short book In Defense of Anarchism. Written in late 1960s America, at the height of public opposition to U.S. involvement in the Vietnam War, the book was in many ways a product of its time. Wolff held that state legitimacy consists of a claim right to obedience, and a correlative obligation of subjects to obey (i.e., political obligation). ${ }^{1}$ He also concluded that no state has such a right. Although some philosophers have argued against Wolff's conclusion, it remains a very common view in political philosophy that there are no legitimate states. ${ }^{2}$

*I am thankful for comments on previous drafts from Thomas Christiano, Richard Dagger, Gerald Gaus, Daniel Jacobson, David Schmidtz, Steven Wall, and Christopher Wellman. I am especially grateful to an anonymous referee for Legal Theory, whose suggestions for improving this essay went far above and beyond the call of duty.

1. I will use the term "subject" rather than "citizen" to avoid implicitly suggesting that states can hold legitimate political authority only over their citizens.

2. For an overview of the debate, see Richard Dagger \& David Lefkowitz, Political Obligation, in Stanford Encyclopedia of Philosophy (Edward N. Zalta ed., 2014), https://plato.stanford.edu/entries/political-obligation/. For a couple of estimations of the current popularity of philosophical anarchism, see William A. Edmundson, State of the Art: The Duty to Obey the Law, 10 Legal Theory 218 (2004); Christopher W. Morris, An Essay on the MODERn STATE (1998), at 214. 
The literature immediately following Wolff used the terms "political obligation" and "legitimacy" interchangeably. But more recently, the interests of political philosophers have shifted to include additional political phenomena that make up the state-subject relationship. Thus several theorists have argued for a revised conception of legitimacy that is broader than political obligation. Their view is that legitimate states do not hold a claim right to obedience, but a bundle of several kinds of rights that paints a more nuanced picture of the normative relationship between states and their subjects. ${ }^{3}$ These philosophers argue that legitimate states must hold rights that, for instance, allow them to change the rights and duties of their subjects, enforce state laws, and render their (i.e., the states') rights to some degree immune from being extinguished. Many versions of this bundle also include rights held by states against external agents, but I will focus on the bundle of rights relationships between states and their own subjects, which I will refer to as legitimate political authority. So under this terminology, "legitimacy" is a broader set of state rights that includes rights held against external agents, as well as the rights included in legitimate political authority. ${ }^{4}$

While the debate that followed the publication of Wolff's book was primarily about which of a few traditional moral principles (e.g., consent, fair play, gratitude, and natural duties of justice) might be employed to generate political obligations, more recent work on the revised bundle of legitimate states' rights has largely abandoned discussion of those principles. Some philosophers have concluded that those principles simply are not capable of producing legitimate political authority, whatever rights are included in that concept. ${ }^{5}$ Others argue that moral principles that might very well have grounded political obligation are not suited to ground legitimate political authority more broadly understood. ${ }^{6}$ In my view both groups are wrong: at least one of the traditional moral principles discussed in the debate over political obligation can also serve as the basis of legitimate political authority, even though the latter concept includes a more diverse set of rights.

I argue that the principle of fair play, which many regard as the most promising basis for political obligation, is also the basis of a compelling account of legitimate political authority. ${ }^{7}$ I will not attempt a full defense

3. One of the clearest revisionist statements is David Copp, The Idea of a Legitimate State, 28 Phil. \& Pub. AfF. 3 (1999).

4. Justifying one set of these rights might be related to the justification of the other, but I will not explore that relationship here. The internal rights seem to be about establishing that there is a special normative relationship between the state and its subjects. The external rights, on the other hand, seem to be largely about the ethics of respecting associations of which one is not a member.

5. E.g., Copp, supra note 3. John Simmons offers the clearest case for this assessment in his classic Moral Principles and Political Obligations (1979).

6. E.g., William A. Edmundson, Political Authority, Moral Powers, and the Intrinsic Value of Obedience, 30 OXFord J. Legal STUD. 179 (2010).

7. On the popularity of fair play accounts of political obligation, see, e.g., Richard Dagger, Philosophical Anarchism and Its Fallacies: A Review Essay, 19 LAW \& PhIL. 391 (2000); George Klosko, Political Obligations (2005). 
of a fair play account in this essay, as that would involve entering into a number of protracted disputes. ${ }^{8}$ I will, however, show how the principle of fair play can be brought to bear on the issue of legitimate political authority. In the first section, I explain my conception of legitimate political authority by specifying the bundle of rights of which it is composed. I then show how the principle of fair play can generate legitimate political authority in the second section by drawing on a neglected feature of the principle-its stipulation that members of a cooperative scheme must reciprocate specifically by submitting to the scheme's rules.

\section{THE RIGHTS OF LEGITIMATE STATES}

If a state is legitimate, it holds a bundle of moral rights. Some of these rights are external, as they concern other states and persons who are not the state's subjects. These include, but are perhaps not limited to, a claim right against interference in the state's internal governance and an immunity right against having its internal rights extinguished. Other rights are internal, meaning that they are held by the state against its subjects. There is some disagreement about what these internal rights consist in, but I will assume that there are four central rights. ${ }^{9}$ A legitimate state holds (1) a claim right that its directives be obeyed, (2) a liberty right to enforce its directives, (3) a power right to alter the rights and duties of subjects, and (4) an immunity right against these rights being extinguished. ${ }^{10}$ All of these are moral, rather than merely legal, rights. Each of these rights is also best understood as pro tanto rather than absolute. That is, for purposes of action-guidance they must be weighed against other moral considerations, by which they may be overridden.

While the idea of claim rights will be familiar to most readers, the other kinds of rights included in this bundle may require further explanation. The taxonomy of rights that I will use comes from Wesley Newcomb Hohfeld's analysis of legal rights, which philosophers have adopted for discussions of moral rights. ${ }^{11}$ A right, in the Hohfeldian system, is an advantage that one holds in relation to a party with a corresponding disadvantage. Hohfeld identifies four types of legal advantage, each of which is a different kind of right: claims, privileges (or liberties), powers, and immunities.

8. In particular, I will bracket for now the issue of whether one can incur fair play obligations without voluntarily accepting benefits from a cooperative scheme.

9. To be clear, nothing about my argument will hinge on the inclusion of all of these (and only these) rights in the bundle. This is simply the bundle that I think best represents the internal rights of legitimate states. As long as legitimate political authority can be analyzed in terms of rights, my fair play account can generate legitimate political authority.

10. The grounds of this internal immunity right are, I think, best understood as different from the grounds of the external immunity right.

11. Wesley Newcomb Hohfeld, Fundamental Legal Conceptions as Applied in Judicial REASONING, AND OTHER Legal Essays (1923). For a helpful overview of the Hohfeldian system of rights, see Judith Jarvis Thomson, The Realm of Rights (1990), at ch. 1. 
A claim right is an advantage corresponding to an obligation that is owed to the holder of the claim right by the person who is under that obligation. A paradigmatic example of a claim right is the right generated for Jones when Smith promises to meet Jones for lunch. By making this promise Smith places himself under an obligation, and Jones holds a correlative claim right against him. Jones thus has a justified demand that Smith meet him for lunch. Similarly, a state with legitimate political authority over Smith has a justified demand that Smith obey its directives. If Smith neglects to do so, he violates a moral obligation to that state.

Liberty rights, by contrast, are the absence of a claim right in others against one's doing the thing that one has a liberty right to do. For example, Smith would have a liberty right to eat lunch alone had he not made the promise to meet Jones. In that event, Jones would have no right to demand that Smith meet him. For a state to have a liberty right to enforce its laws, then, the persons subject to that state's enforcement of the law must have no claim right against its doing so. ${ }^{12} \mathrm{~A}$ further feature of the state's liberty right to enforce its laws is that it has a claim right against anyone interfering with that enforcement. Thus this liberty right is a protected liberty-a liberty right the exercise of which is protected by a claim right.

A power right is an ability to alter the set of rights held by oneself or others. Those subject to another person's power right have a corresponding liability to having their rights changed. Promising is an exercise of a power right, as it puts the promisor under a newly created obligation to the promisee, for whom a correlative claim right is generated. So in the Smith-Jones lunch case, promising (i.e., the exercise of a power right) is the process through which the claim right and correlative obligation are created. Power rights can also involve more complicated alterations, as they may in principle be used to create or extinguish any of the four kinds of rights discussed here, depending on the scope and type of power invested in the holder of the power right. The scope of a power right may be very narrow. Jones may, for instance, grant Smith a power right to choose between two restaurants for lunch. But legitimate political authority involves a rather extensive power right, as legitimate states may alter the rights of their subjects across a wide area of life by exercising their legislative and judicial powers.

Finally, an immunity right is the correlate of the lack of a power right (also called a disability) in others to alter one's rights. In the absence of other arrangements, I have an immunity right against others issuing promises on my behalf and so waiving my liberty rights by putting me under obligations. Legitimate political authority includes an immunity right against the state's rights being extinguished or otherwise altered by its subjects. Like all the other rights in this bundle, this immunity right is limited in scope, as subjects

12. For a recent statement and defense of this view with respect to punishment, see Christopher Heath Wellman, The Rights Forfeiture Theory of Punishment, 122 ETHICs 371 (2012). Some would hold instead that those being punished retain their claim right, but that it is overridden. And still others hold that there is no claim right against being punished. 
may hold a power right to, for instance, alter the constitution through some prescribed procedure. The immunity right simply limits the power of subjects to make these alterations through other means.

These are the rights that a successful account of legitimate political authority must justify. I will now develop such an account based on the principle of fair play.

\section{FAIR PLAY AND LEGITIMATE AUTHORITY}

The principle of fair play has long been used to argue that the subjects of reasonably just states have an obligation to obey the law, and that such states have a correlative claim right to obedience. ${ }^{13}$ While those arguments might establish that fair play can generate political obligations, they do not attempt to justify the full bundle of rights that make up legitimate political authority. I will argue that the principle of fair play has untapped resources that can generate the rest of the rights in that bundle. More specifically, I will argue that H. L. A. Hart's version of the principle can produce these rights by drawing on his insights about rules in his legal philosophy.

Hart provides the following canonical formulation of the principle of fair play: "when a number of persons conduct any joint enterprise according to rules and thus restrict their liberty, those who have submitted to these restrictions when required have a right to a similar submission from those who have benefited by their submission." "In order for a cooperative scheme to generate fair play obligations, it must meet certain conditions of fairness. Developing a full account of these conditions is a task outside the scope of this paper, but they include at least the following: (i) the benefits that the scheme provides must be worth the cost, and (ii) the distribution of the scheme's benefits and burdens must be fair. The fair play argument for an obligation to obey the law is relatively straightforward. Subjects of a reasonably just state enjoy the benefits of the rule of law because the vast majority of subjects submit to the rules of the legal system. In other words, they receive a benefit made possible by the costly submission of others, and so incur a debt of fairness to reciprocate. Accordingly, each subject owes to her fellow subjects an obligation to obey the law, and each subject holds a correlative claim right against all the others that they obey the law. ${ }^{15}$

13. See Richard Dagger, Civic Virtues: Rights, Citizenship, and Republican Liberalism (1997); Noam Gur, Actions, Attitudes, and the Obligation to Obey the Law, 21 J. Pol. PhIL. 326 (2012); George Klosko, The Principle of Fairness and Political Obligation (rev. ed. 2004); Klosko, Political Obligations (2005); John Rawls, Legal Obligation and the Duty of Fair Play, in Collected Papers (Samuel Richard Freeman ed., 1999); Edward Song, Acceptance, Fairness, and Political Obligation, 18 LEGAL THEORY 209 (2012).

14. H. L. A. Hart, Are There Any Natural Rights?, 64 PHIL. REv. 185 (1955).

15. Of course, the account becomes more complicated when the conditions of fairness are not met-for instance, when some do not receive a fair share of the benefits-but this need not detain us. 
It is harder to see how the principle of fair play might justify the rest of the rights of legitimate political authority. The chief difficulty seems to be that the principle, as stated, generates only claim rights. But we have seen that legitimate states hold several types of rights against their subjects. In the case of power rights in particular, it seems that fair play faces an order of justification problem. A legitimate state must have a standing moral power to issue authoritative directives. Since a state directive invokes a moral power, its subjects ought to obey a directive simply because the state issued it, just as one ought to keep a promise simply because promising invokes a moral power. But if no one has benefited yet from a state directive, then there is no debt of fairness that must be repaid by submitting to that directive. Thus, it would seem that there can be no fair play justification for a power right.

One possible strategy for circumventing the order of justification problem is to note that subjects might adopt a state directive as a coordination point. That is, regardless of whether subjects are morally required to obey a state directive simply because the state issued it, they might obey anyway. Their cooperation could produce benefits, and so generate fair play obligations for those who receive those benefits to follow the directive, too. Suppose, for instance, that a state builds a network of roads and declares that people should drive on the right-hand side. Even if drivers have no duty to drive on the right simply because of the state's directive, they might treat the directive as a salient coordination point. Their coordination would produce the benefit of safer roads, and so other drivers could have a fair play obligation to drive on the right in order to reciprocate. In such a scenario the state's directive apparently has the same end result as the exercise of a power right - the creation of an obligation to obey.

A state without moral powers could still change the duties of its subjects by proposing coordination points. But something important is missing from such a picture. David Estlund contrasts two ways of altering rights and duties. One method is to exercise a power right, by which one alters rights and duties through normative means. Another method is to exercise what Estlund terms a side effect power-an action that brings about a moral requirement or prohibition through causal means. ${ }^{16}$ For instance, I may put myself in peril and so create a duty for others to rescue me. But here the creation of that duty is incidental, and no part of the point of the act. Surely the state's ability to change its subjects' rights and duties is more than a mere side effect power. It seems, rather, to be a genuine moral power, like promising. ${ }^{17}$ So the principle of fair play will need to account for actual power rights, and not just some makeshift substitute.

Fortunately, the principle has a simple but theoretically powerful resource that allows it to generate power rights, as well as the rest of the rights of

16. David M. Estlund, Democratic Authority: A Philosophical Framework (2008), at 143.

17. For a fuller statement of this concern, see Edmundson, supra note 6 . For a longer discussion of this problem, see my The Possibility of a Fair Play Account of Legitimacy, 30 RATIO 88 (2017). 
legitimate political authority. In Hart's formulation, he notes that the cooperative scheme governed by the principle of fair play must be conducted "according to rules." This rules condition is what separates obligations of fair play from other obligations of reciprocity. Obligations of gratitudeanother kind of obligation of reciprocity - can arise where the action that prompts them is not an instance of rule-following. I should, for instance, be appropriately grateful to you for helping me jump-start my car, despite there being no rules about my owing you anything in particular.

In the debate about political obligation, most defenders of fair play have invoked the rules condition only as a necessary condition for the applicability of the principle. So, for example, some fair play theorists have argued that Robert Nozick's famous example of foisting benefits on people by throwing books into their houses is not actually an embarrassing counterexample for the principle because the case does not satisfy the rules condition. ${ }^{18}$ Because the terms of success for establishing political obligation involve generating only a claim right, there has been no need until recently to ask whether the principle can do more. Nor has there been any reason to ask whether rules might play any more significant role in the principle of fair play.

As I interpret the principle, the rules condition is not merely a necessary condition for its applicability, but a key part of the machinery of fair play. The rules of a cooperative scheme give content to what Hart calls "similar submission." Those already participating in the scheme have submitted to the costs laid out in the scheme's rules, and recipients of the benefits of the scheme owe it to those participants to submit in kind-that is, to the same rules. The form that repayment must take is not up to the discretion of the obligation-bearer. That is because part of the burden assumed by all is having one's repayment options restricted to what the rules specify. Thus, no other form of repayment could be truly reciprocal, as it would shirk this burden.

Allowing rules to serve this function makes the terms of fair play fixed from the perspective of cooperators, but importantly flexible in another sense. Because the rules fix the content of fair repayment, cooperative schemes are able to use rules to specify the rights relationships between persons holding different positions in the scheme. And since the principle of fair play generates a moral obligation to submit to the cooperative scheme's rules, the rules themselves acquire moral backing. For example, suppose that a neighborhood forms a cooperative scheme to dig and maintain a communal well, and that the well produces benefits for the neighbors. As a result, they have a fair play obligation to submit to the rules of the scheme. Suppose further that in order to address the contingencies that may affect the proper functioning of the well, the neighbors establish a rule that grants Jones the power to assign emergency maintenance to a participant of his choosing as it becomes appropriate. Assuming that Jones

18. Robert Nozick, ANarchy, State, And Utopia (1974), at 90-95. 
exercises his power fairly, he may establish an obligation for any participant to perform emergency maintenance. Every participant would have a moral claim right that the chosen participant perform maintenance, but Jones would also hold a moral power right to impose such obligations. Moreover, all participants would be under a correlative moral liability to having Jones assign them emergency maintenance obligations. This example reveals that the principle of fair play can generate rights other than claim rights. The claim right to rule-submission held by each participant against all the others is the fundamental moral relationship, but other rights can be derived from it through the rules of the scheme. We can tell a similar-though more complicated-story about rules and the rights of legitimate political authority.

For that story to work, though, it is critical that the rules of a cooperative scheme actually do specify what it means for participants to play fair. But Jiafeng Zhu has argued recently that the principle of fair play cannot deliver on its claim to require rule-following. ${ }^{19} \mathrm{Zhu}$ allows that the recipients of benefits may owe some form of repayment to the scheme, but claims that there is a "justificatory gap" between that requirement and a requirement that repayment come specifically through submission to the scheme's rules. If fair play is simply about the fair distribution of benefits and burdens, there are many ways that one might bear one's fair share of a scheme's burdens. To return to the well example, perhaps a participant could refuse to submit to Jones's order but bear his fair of the costs by, say, installing a more efficient pump for the well. A fair play theorist might argue that the liberty to choose the form of repayment is an extra benefit not enjoyed by others, but Zhu could simply respond that the extra benefit can be repaid by submitting to a costlier alternative burden. So the participants of a cooperative scheme may have a claim right to repayment from the beneficiaries of their cooperative efforts, but beneficiaries retain a liberty right to choose the form of repayment.

If there is such a justificatory gap, it presents a serious problem for a fair play account of legitimate political authority. The problem is that if people can repay their debts of fairness by providing any return of appropriate value rather than submitting to the rules, then the state only has a right to a repayment of similar value to what it provides. It could not hold anything as definite as the rights of legitimate political authority as a matter of fair play, because beneficiaries retain a liberty right to choose the form of repayment. They need not submit to any specific set of rules.

It must be admitted that Zhu's argument has some intuitive pull. Most people have, at one time or another, run up against a legal requirement that makes some inefficient demand on them. It is natural in such situations to think that one could bear one's fair share of the burdens of cooperation

19. Jiafeng Zhu, Fairness, Political Obligation, and the Justificatory Gap, 12 J. Moral Phil. 290 (2015). 
through some alternative means that is less wasteful, does more good, or is better suited to one's abilities. For instance, perhaps an engineer could create a more effective emissions system for his car instead of paying a carbon footprint tax. If fair play is simply about restoring a fair distribution of benefits and burdens, why should we fixate on submission to the official set of rules, rather than accept any number of alternative repayments of similar value?

I suspect that there are approximately as many responses to this question in defense of fair play as there are arguments in favor of an obligation to fulfill one's side of a contract as stipulated in the terms of the agreement, rather than through some payment of similar value. ${ }^{20}$ Here I offer an intuitive case. There are situations in which we make moral commitments to submit to conventional rules without displaying any sign of consent-tacit or express-and the principle of fair play offers the best explanation for the moral force of those commitments. ${ }^{21}$ Take, for instance, a public transit system in which passengers pay their fares on an honor system. If you were to walk past the ticket vending machines and board the train without paying, then a highly intuitive evaluation of your behavior is that you have done something wrong in refusing to follow the same rules as the ticketpurchasing passengers. Zhu's preferred explanation of such cases is that you have violated a tacit agreement by boarding without paying. ${ }^{22}$ But your behavior as described conveys quite clearly that you do not agree to follow the rules.

The explanation supported by the principle of fair play is much more plausible: by accepting the benefits of the public transit system, you have incurred an obligation to submit to the system's rules. But suppose that Zhu is right, and there is a justificatory gap-rather than pay your fare, you may instead act as a delightful conversationalist for the other passengers, or advise the conductor about optimal speeds, or heretofore undiscovered shortcuts, and all this to a degree of value equal to the cost of a ticket. Even if such alternative payments were workable, any scheme in which such discretion in form of payment were allowed would likely fail, as beneficiaries would choose the most convenient form of payment rather than the one most needed to support the working of the scheme. But that means that, unless my claim about our being intuitively obligated to support such schemes is false, something has gone wrong. One of the main purposes of moral principles of commitment is to bind people to courses of action that solve problems of social coordination, even when for whatever reason their private judgment recommends some alternative action. Since consent cannot explain why we must follow the rules in the case just considered and

20. I have also discussed this issue in Rethinking the Principle of Fair Play, Pac. PHIL. Q. (forthcoming) and Playing Fair and Following the Rules, 14 J. Moral PHIL. 134 (2017).

21. On the requirement of a sign of consent for an obligation to be generated by the principle of consent, see Simmons, supra note 5, at 64.

22. Zhu, supra note 19, at 299-302. 
those relevantly similar to it, we need some alternative explanation. The principle of fair play offers a plausible explanation, but only if we deny that there is a justificatory gap. In the absence of some better alternative, that is what I suggest we do. Thus, since the rules of cooperative schemes set the terms of fair repayment, schemes may use them to create a specific set of rights, like those that make up legitimate political authority.

I turn now to explaining how states specify the rules that fair play turns into the moral rights that make up legitimate political authority. Given the role of rules in the fair play account, much of the work of establishing the rights of states is done by working out what rule would establish the appropriate right. If a state has a rule and provides a fair distribution of benefits and burdens to its subjects, then the subjects are committed to submitting to that rule just as if they had agreed to a contract with similar terms.

The rights to be established are, again, (1) a claim right that state directives be obeyed, (2) a liberty right to enforce those directives, (3) a power right to alter the rights and duties of subjects, and (4) an immunity right against these rights being extinguished. The rules specifying these rights are of two types, familiar from Hart's analysis of the rules of modern legal systems. ${ }^{23}$ Primary rules specify the permissions, entitlements, and protections that are characteristic of claim rights and liberty rights. These are the rules that specify what members and officers of the scheme are owed, what they are free to do, and what their responsibilities are. Secondary rulesthat is, rules about rules-specify the second-order normative abilities and protections associated with power rights and immunity rights. These rules specify who may make changes to the scheme's primary rules, and how they may do so.

The principle of fair play generates a claim right held by members of the cooperative scheme to similar submission from recipients of the benefits they provide. Again, this claim right is the fundamental right from which all other rights of political authority are derived. Participants in the scheme owe it to one another to submit to all of the conventional rules specifying the rights of political authority because each holds this claim right to similar submission against all the others.

The state's claim right to obedience is best understood as a separate claim right. It is not the right to similar submission generated directly by the duty of fair play. Rather, it arises from the promotion of one of the scheme's conventional rules into a moral rule. The purpose of this claim right is to establish that infractions of the scheme's rules are wrongs directed at a certain set of persons. So when a subject of the state commits a crime, and so violates the scheme's primary rules, it is as if he commits two wrongs: one against every member of the scheme for not playing fair, and another against the persons specified by this claim right as the holders of the correlative right to obedience.

23. H. L. A. HaRT, The ConcePt OF LaW (2d ed. 1994), 80-81. 
This second, derivative claim right has explanatory utility for some common but perhaps prima facie odd features of modern states. For instance, it makes sense of the practice of the state as body politic being named as plaintiff in criminal cases (e.g., United States v. Doe) even though in some sense most crimes are a private matter between victim and wrongdoer. Relatedly, it is an expression of the different roles citizens and noncitizens have in the state. Though both groups participate in the cooperative scheme, they hold different degrees of membership, and thus one holds a share of the claim right to obedience and the other does not. Finally, even if we understand the state as a collective agent constituted by its individual citizens, the second claim right is necessary, because the scheme could be organized differently. The wrong of unfairness could be directed against all the members of the scheme, while the wrong of disobedience could be against only the legislature, the monarch, or some other office.

The communal well case provided one example of the principle of fair play generating a power right. The case of the state is similar, though its power is more extensive. The state's power right to make changes to its subjects' rights is represented in the scheme's rules by rules of changeone type of secondary rule. Rules of change confer upon certain officials the ability to make changes to the scheme's primary rules. These rules grant moral powers to officials, as they allow them to alter the rights of subjects by changing the primary rules of the cooperative scheme. Constitutional rules providing for the state's legislative function-those enumerating the powers of the legislature and the limits of those powers-and the powers of the judiciary are the clearest examples of this kind of rule. So when the legislature passes a new legal restriction (and so creates an obligation) or repeals an old restriction (and so creates a liberty), it exercises the power right afforded to it by rules of change. As Hart points out, modern legal systems also invest the legislature with the power right to confer moral powers to others. ${ }^{24}$ For state subjects, being liable to have their normative situation changed by the state in these ways is part of the burden of playing fair. Being told what to do is a cost, and it must be weighed along with the other burdens of cooperation against the benefits that the scheme provides.

The state's liberty right to enforce its directives runs up against a number of contentious normative issues, as this right depends on the successful justification of state punishment. Some of the work in such a justification cannot be done by the principle of fair play alone. In particular, the question of how severely a criminal may be punished seems to depend on other moral considerations. The legal constraint against murder is no great burden for most people, so claiming an extra liberty for oneself by committing a murder is a minor violation in terms of fair play. To justify the intuitively appropriate harsh punishment for murderers, then,

24. Hart's favored example of such conferral is the law establishing criteria for a valid will. 
one would need to appeal to an independent value such as desert or utility. ${ }^{25}$

But there are other questions bearing on the liberty right to enforce the law to which fair play has compelling answers. For one thing, the principle can again make use of the rules of the cooperative scheme to specify who holds the liberty right to punish criminals. That right is allocated through primary rules about which offices in the state hold executive powers. Precisely how this allocation works depends on the natural rights and duties related to punishment. If Locke is right that everyone has a natural right to punish wrongdoers, then the rules of the scheme may call for the transfer of this right to the scheme, which then allocates it to certain officials. Alternatively, the rules may simply call for the forfeiture of this right from all members who do not hold the appropriate office.

If, on the other hand, no one holds a natural right to punish, then fair play must explain how it could be permissible for anyone to punish another person. More specifically, it must explain why state officials have a liberty right to punish people for behaving unfairly. Here again, the necessary reallocation of rights can be built into the cooperative scheme's rules. The rules may specify that criminals forfeit their claim right not to be punished by the state when they break the law. In violating the rules, criminals take for themselves an unfair share of liberty. While the other members generally submit to the rules, and thus make possible the provision of benefits, criminals enjoy those benefits without taking on their fair share of the burdens of cooperation. Such unfair behavior is a wrong against the rule-abiding members of the cooperative scheme, and in order to restore a fair distribution of benefits and burdens among members, the scheme may punish them.

Finally, the state's immunity right against subjects altering its rights is both implicit in the principle of fair play and also possibly included in constitutional rules about the power of subjects to change the state's laws. It is implicit in fair play because the principle implies that subjects can only extinguish the state's political authority over them by paying off their debt of fairness. Otherwise, they would not be giving other members the similar submission specified by the rules. They would be claiming for themselves an additional liberty to decide how to repay their debt of fairness-a liberty that others do not have the privilege of exercising.

Additional contours of the state's immunity rights may be codified in the rules. For instance, there could be constitutional or lesser legal provisions granting the state's subjects power to change the state's rights through some specified procedure-i.e., through referenda or constitutional amendments. While these rules confer powers to the state's subjects, they also implicitly limit what subjects may do. If the state's rights can only

25. For more detailed discussions of the fair play justification of punishment than I can venture into here, see Richard Dagger, Playing Fair with Punishment, 103 Eтнісs 473 (1993); Zachary Hoskins, Fair Play, Political Obligation, and Punishment, 5 Crim. L. \& PHIL. 53 (2011); Herbert Morris, Persons and Punishment, 52 THE Monist 475 (1968). 
be changed through certain procedures, then that means its subjects are disabled from changing them through other means. And the correlate of a Hohfeldian disability is an immunity right.

If a state or some other political association has these rules, and meets the criteria of the principle of fair play, then the members of those associations owe one another an obligation of fair play that grounds legitimate political authority. In other words, the state's conventional rules specify the rights conferred to persons upon their becoming members of the cooperative scheme. This allocation of rights transforms the state's rules into moral rules, just as consent by multiple parties to the terms of a contract grants its provisions moral force between them.

\section{CONCLUSION}

As political philosophers have expanded the scope of their inquiry into the moral evaluation of states, the task of defending states has become more difficult. My aim in this essay has been to show that discussion of the larger issue of state legitimacy can draw from the already extensively developed fair play account of political obligation. I do not pretend to have addressed all of the obstacles facing a fair play account of legitimate political authority. But I have here worked out the core material for such an account. I have shown that the principle of fair play can generate the bundle of rights that make up legitimate political authority, and that the key theoretical resource for doing so is the rules condition that has been a part of the principle since Hart's initial formulation of it. Fair play has long been considered the most promising basis for political obligation. It should also be considered a promising basis for legitimate political authority. 